\title{
Effect of Soaking and Cooking Methods on Extraction of Solids and Acceptability of Tiger Nut (Cyperus Esculentus L) Milk
}

\author{
Frank A. Asante (Corresponding author) \\ Cocoa Processing Company Limited, PMB, Tema, Ghana \\ E-mail: asantefrank@yahoo.com
}

William O. Ellis

Department of Food Science and Technology, College of Science

Kwame Nkrumah University of Science and Technology, kumasi-Ghana

E-mail: elliswo@yahoo.com

\begin{abstract}
Ibok Oduro
Department of Food Science and Technology, College of Science

Kwame Nkrumah University of Science and Technology, kumasi-Ghana

E-mail: iquomma@yahoo.com
\end{abstract}

Firibu K. Saalia

Department of Nutrition and Food Science, University of Ghana

P.O. BOX LG 134, Legon Ghana

E-mail: fsaalia@ug.edu.gh

Received: May 6, 2014 Accepted: June 3, 2014

doi:10.5296/jas.v2i2.5991 URL: http://dx.doi.org/10.5296/jas.v2i2.5991 


\section{Abstract}

Vegetable milk is a nutritious alternative for consumers who for dietary and other constraints cannot consume dairy milk. The production of vegetable milk solids of acceptable taste and quantity is however an important consideration. The study determined the effect of soaking in combination with boiling, steaming and roasting on the yield of milk, solids and its sensory quality. Boiling of tubers before soaking yielded the highest quantity of milk for all tubers with a range of $4395.5 \mathrm{~g} \mathrm{~kg}_{-}{ }^{1}$ to $6530.4 \mathrm{~g} \mathrm{~kg}_{-}{ }^{1}$. Boiling before soaking however gave the lowest milk solids for the tubers with the lowest and highest recorded as $101.0 \mathrm{~g} \mathrm{~kg}_{-}{ }^{1}$ and $139.0 \mathrm{~g} \mathrm{~kg}_{-}{ }^{1}$ respectively. Expected milk solids for all pre-treatments ranged from $541.4 \mathrm{~g} \mathrm{~kg}^{-1}$ to $619.4 \mathrm{~g}$ $\mathrm{kg}-^{1}$ for black tubers and $571.4 \mathrm{~g} \mathrm{~kg}-^{1}$ to $710.2 \mathrm{~g} \mathrm{~kg}_{-}{ }^{1}$ for the brown tubers.

Roasting before soaking of brown tubers enhanced the flavor of milk however there were no differences in overall acceptability of milk extracted from different pre-treated tubers. This sequence of pretreatments will enhance the extraction of good quality tiger nut milk and solids to broaden its utilization as ingredient in the food industry.

Keywords: Tiger nut tubers, Pre-treatments, Milk yield, Expected milk solids, Sensory evaluation

\section{Introduction}

Non-dairy milk has for some time now attracted a lot of interest because of the scarce supply of cow milk in developing countries and its relatively lower cost. Dietary constrains, allergens, religious convictions, ethical reasons and the growing awareness of its nutritional value are other reasons that has heightened its interest (Wang, 1980; Edwards, 1998; Diarra, Nong and Jie, 2005, El-Agamy, 2007). Non-dairy products that have attracted a lot of interest are Soy milk, safflower milk, rice milk, peanut milk and tiger nut milk (Edwards, 1998; Russell and Delahunty, 2004; Kashid, Sontakke and Shined, 2007; Isanga and Zhang, 2009; Rubert, Soler and Manes, 2011).

Tiger nut milk, popularly called "atadwe" milk by Ghanaians and "horchata de chufa" after sugar is added is a very popular drink in Ghana, Spain and some South American countries (Dokosi,1998; Cortés, Esteve, Frgola and Torregrosa, 2004). The refreshing non-alcoholic beverage of milky appearance has high nutritional quality with great market potential (Cortés, Esteve, Frgola and Torregrosa, 2005). It is high in starch glucose and proteins. It is also rich in minerals like potassium, phosphorus, vitamin E and C (Tigernut traders, 2010 ) Tiger nut milk is also reported to contain myristic, linolenic and large amounts of oleic acid (Belewu and Belewu, 2007) It is commonly produced from dried tubers which are pre-treated by soaking in water. The hydrated tubers are then milled in water to extract the milk. Pre-treatment of plant materials is a major process step in the extraction of non dairy milk. It is an important activity that affects the milk yield, quality, sensory characteristics, solids extracted and shelf life (liener 1994; Liu, 1997; Aidoo, et al., 2010). Soaking and boiling have extensively been used to pre-treat tiger nut tubers before extraction of milk and solids (Mosquera et al., 1996; Ndjouenkeu and Djomdi Ejoh, 2007; Sanful, 2009). There is however a dearth of information on the effect of other cooking methods on the yield of solids and acceptability of milk. The 
objective of this study therefore was to determine the effect of soaking and different cooking methods of tiger nut tubers on the yield of milk, solids and sensory quality of two varieties of tubers from eight different sites in Ghana.

\section{Materials and Methods}

\subsection{Samples}

Six samples each of two varieties of tiger nut tubers (Cyperus esculentus L.) grown at eight different sites in Ghana (Ampenyi, Bawjiase, Danyameso, Ebu, Kwahu Aduamoa, Tampiong, Tanoso Twifo Praso, were studied. The tubers were sorted, washed and dried in a Sanyo oven (Model MOV-212, Japan) at $55^{\circ} \mathrm{C}$ till moisture was between 7 to $10 \%$ before evaluation.

\subsection{Tiger Nut Milk Extraction Procedures}

The procedure for screening different varieties of tubers from different sites for milk and solids extraction is shown in Figure. 1.

$100 \mathrm{~g}$ of oven dried nuts were soaked in covered vessels with $600 \mathrm{~mL}$ of water for 12 hours. The water was discarded and the nuts milled in a Waring blender at high speed in twice its new weight of water for 5 minutes. The milk was pressed through a cheese cloth until no more extract was obtained to receive the milk and the weight determined for analysis.

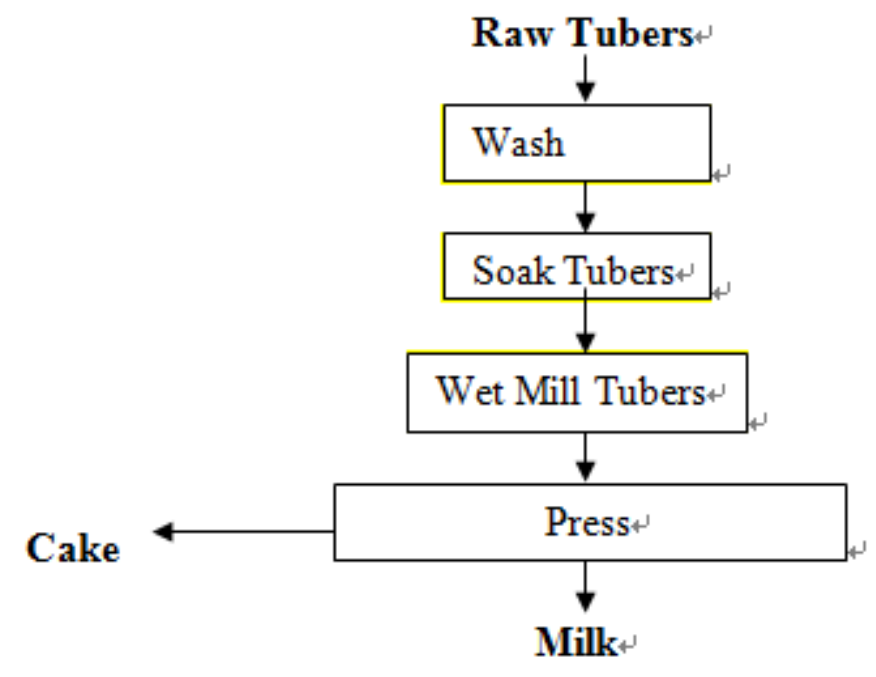

Figure 1. Flow Diagram for screening different varieties of tubers from different sites for milk and solids

The pre-treatment methods (soaking and cooking) used for tubers from selected sites after screening are shown in Figure 2. Three main extraction procedures were evaluated. A: soaking only, B: soaking of tubers before cooking and C, cooking of tubers before soaking. One hundred grams (100 g) oven dried tubers were used for the milk extraction. In processing method A, the tubers were soaked in covered vessels for 6 hours; and then wet milled for milk extraction. In process B, the tubers were also soaked in covered vessels for 6 hours then tied in a piece of muslin cloth and boiled for 10 minutes. Another set of $100 \mathrm{~g}$ of tubers were soaked for $6 \mathrm{hrs}$ and steamed on a sieve over boiling water for 10 minutes. Yet another set of $100 \mathrm{~g}$ 


\section{Macrothink}

Journal of Agricultural Studies

ISSN 2166-0379 2014, Vol. 2, No. 2

Tubers were soaked for 6 hours and roasted on trays in a hot air oven pre heated to $180^{\circ} \mathrm{C}$ for 10 minutes. Each of the samples of the three sets was milled in a Waring blender at high speed in twice its new weight of water for five minutes to facilitate milk extraction.

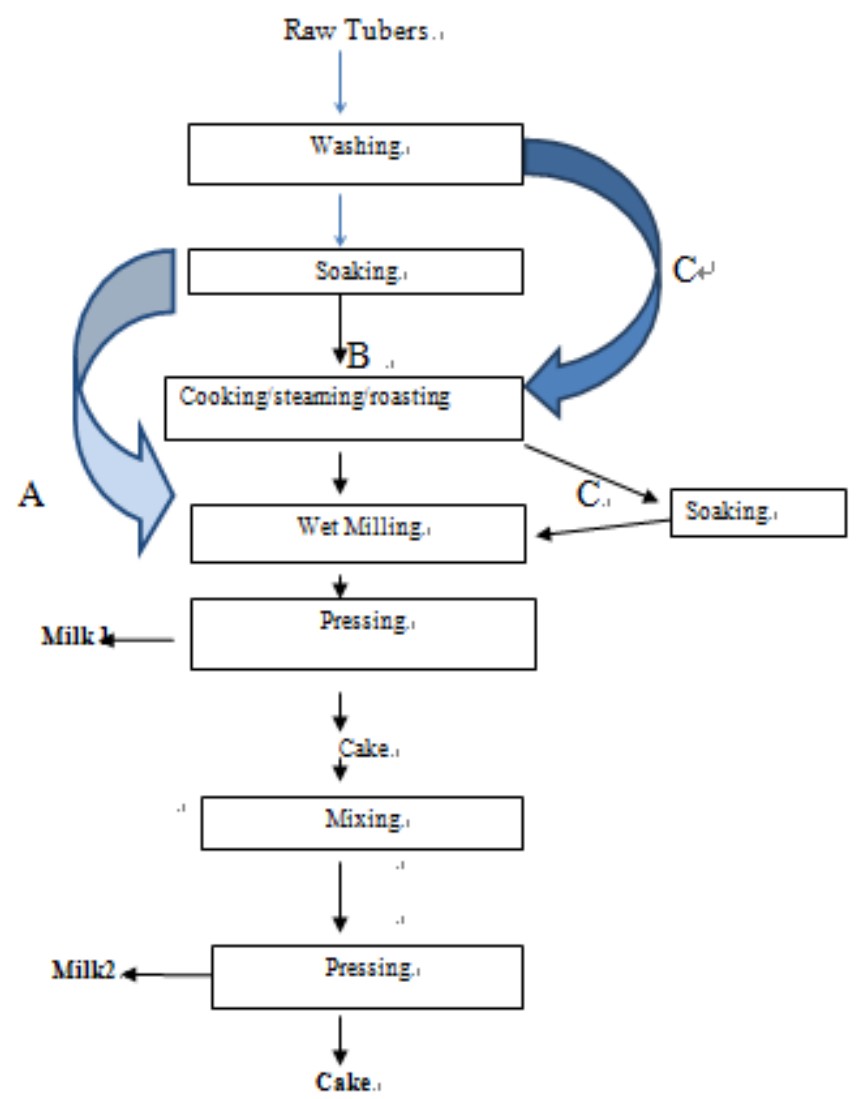

Figure 2. Flow diagram for extracting milk and solids from different pre-treated tubers

The first milk extract was obtained by pressing the extract through a cheese cloth until virtually no more liquid was available for extraction. Re-extraction of milk was done by adding same volume of water used for initial extraction to the cake. The mixture was stirred and pressed again through a cheese cloth until virtually no more extract was available to obtain the second milk extract. In pre-process method $\mathrm{C}$, nuts were cooked (boiling, steaming and roasting) before soaking. (Figure 2)

Milk and solids indices were determined as follows;

Percentage Milk Extracted $(\mathrm{ME})=(\mathrm{W} 2 / \mathrm{W} 1) \times 100$

$\mathrm{W} 2$ = weight of extracted milk

$\mathrm{W} 1=$ weight of tubers

Percentage Milk Solid (MS) of milk was determined as;

$\mathrm{MS}=\mathrm{W} 3 / \mathrm{W} 2 \quad \mathrm{x} 100$

$\mathrm{W} 3=$ Weight of dry powder

Percentage expected milk solid (EMS) was determined as;

$\mathrm{EMS}=\mathrm{MS} \times \mathrm{ME}$ 


\subsection{Evaluation of Sensory Quality of Milk after Pre Treatments}

The seven samples obtained were evaluated using a balanced incomplete block (BIB) design $(\mathrm{t}=7, \mathrm{k}=4, \mathrm{r}=20, \mathrm{~b}=35 \lambda=10)$ (Cochran \& Cox, 1957) with a trained panel of 35 persons. All the samples were sweetened with the same amount of sugar per weight ( $20 \mathrm{~g} \mathrm{~kg}^{-}{ }^{1}$ milk) and were evaluated for flavor, after taste and overall acceptability on a nine point hedonic scale with 1 representing least liked and 9 most liked. Water was available for panelists to rinse their mouths and they were allowed to re-taste samples.

\subsection{Statistical Analyses}

The General linear Model was used to determine the differences in treatments using MINITAB 14 statistical package (MINITAB Inc., U.S.A.). Tukey's test was used to identify significant differences among treatment means $(\mathrm{p}<0.05)$.

\section{Results and Discussion}

The yield indices of tiger nut milk are shown in Table 1. There were significant differences in milk extracted (ME), milk solids (MS) and expected milk solids (EMS) between the varieties and the sites investigated.

\subsection{Effect of Site on Yield of Milk Solids from Different Varieties of Tubers}

Ampenyi, Bawjiase, Danyameso and Ebu were the sites where both varieties were planted at the same time. With the exception of Ebu where milk solids from the two varieties of tubers were not significantly different, the results from Table 1 show significant differences in all other indices measured for the different varieties on the same site.

Table 1. Yield of milk and solids of tubers from different sites and varieties

\begin{tabular}{|c|c|c|c|c|}
\hline \multirow[t]{2}{*}{ VARIETY } & \multirow[t]{2}{*}{ SITE } & \multicolumn{3}{|c|}{ MILK CHARACTERISTICS } \\
\hline & & $\mathrm{ME}\left(\mathrm{g} \mathrm{kg}_{-}{ }^{1}\right)$ & $\operatorname{MS}\left(\mathrm{g} \mathrm{kg}^{1}\right)$ & EMS (g kg- ${ }^{1)}$ \\
\hline \multirow{6}{*}{ BLACK } & Ampenyi & $2706.3(4.2)^{\mathrm{c}}$ & $159.4(1.3)^{\mathrm{a}}$ & $431.4(4.0)^{\mathrm{a}}$ \\
\hline & Bawjiase & $2587.2(9.8)^{d}$ & $155.2(0.1)^{b}$ & $401.6(1.5)^{\mathrm{b}}$ \\
\hline & Danyameso & $2275.0(12.4)^{\mathrm{e}}$ & $150.1(1.4)^{\mathrm{c}}$ & $341.5(2.2)^{\mathrm{c}}$ \\
\hline & Ebu & $2661.3(3.5)^{f}$ & $157.1(0.7)^{\mathrm{ab}}$ & $418.1(1.8)^{d}$ \\
\hline & Tampiong & $2856.7(2.1)^{g}$ & $16.24(0.7)^{\mathrm{d}}$ & $464.0(2.3)^{\mathrm{e}}$ \\
\hline & Tanoso & $2991.2(1.3)^{\mathrm{h}}$ & $14.59(0.9)^{\mathrm{e}}$ & $436.5(2.5)^{\mathrm{a}}$ \\
\hline \multirow{6}{*}{ BROWN } & Ampenyi & $2333.0(2.3)^{\mathrm{i}}$ & $145.7(1.0)^{\mathrm{f}}$ & $340.0(2.3)^{f}$ \\
\hline & Bawjiase & $2652.2(12.5)^{\mathrm{a}}$ & $147.2(0.9)^{\mathrm{g}}$ & $390.4(3.0)^{g}$ \\
\hline & Danyameso & $2721.8(19.3)^{j}$ & $137.6(1.1)^{\mathrm{h}}$ & $374.5(5.5)^{\mathrm{h}}$ \\
\hline & Ebu & $2627.7(10.8)^{\mathrm{ab}}$ & $157.2(0.7)^{\mathrm{i}}$ & $399.7(3.3)^{\mathrm{i}}$ \\
\hline & Kwahu Aduamoa & $2788.0(2.5)^{\mathrm{k}}$ & $164.0(1.0)^{j}$ & $457.1(2.2)^{\mathrm{j}}$ \\
\hline & Twifo Praso & $2612.8(2.6)^{\mathrm{b}}$ & $171.8(1.4)^{\mathrm{k}}$ & $449.0(4.1)^{\mathrm{j}}$ \\
\hline
\end{tabular}


Key: ME, Percentage Milk Extraction; MS, Percentage Milk Solids; EMS, Expected Milk Solids. Tukey's test was used to locate differences in means.

Means in the same column but with different superscripts differ significantly $(p<0.05)$.

This observation could be due to the differences in weights and sizes of the different varieties of tubers. Tanoso black recorded the highest milk yield of $\left(2991.2 \mathrm{~g} \mathrm{~kg}^{1}\right)$ whereas Danyameso black recorded the lowest milk yield of $\left(2275.0 \mathrm{~g} \mathrm{~kg}^{-}\right)$. The highest milk solids of $\left(162.4 \mathrm{~g} \mathrm{~kg}^{-1}\right)$ was recorded by Tampiong black making it the sample with the potential to yield the highest expected milk solids of $464.0 \mathrm{~g} \mathrm{~kg}^{1}{ }^{1}$ with Ampenyi brown expected to yield the lowest expected milk solids of $340.0 \mathrm{~g} \mathrm{~kg}^{1}$

Though milk extracted from Tanoso black tubers was the highest, and the expected milk solids the second highest, Ampenyi black was selected alongside Tampiong black, Kwahu brown and Twifo Praso brown tubers for the next phase of the study. This was because these tubers gave higher milk solids. The results on milk yield, milk solids and expected milk solids after different combination and sequence of soaking and cooking are shown in figures 3,4 and 5 below. The data revealed significant variations in characteristics of milk extracted after different pre-treatments and significant yield of solids in re-extractions. The findings are similar to milk extraction studies conducted on other plant materials (Tunde-Akintunde and Souley, 2009; Quasem, Mazahreh and Abu-Alruz, 2009, Ye and Jiang, 2011).

Soaking and heat treatment of plant materials is an important step in the production of vegetable milk because it eliminates anti nutritional factors, makes milk more palatable and digestible, and tenderizes plant materials to facilitate milling and extraction (Liu, 1997; Enneking and Wink, 2000; Adekanmi, Oluwatooyin and Yemisi, 2009). Figure 3 shows that for all sites and varieties, boiling before soaking of tubers yielded the highest milk for both varieties. Tubers (brown variety) obtained from Twifo Praso recorded the highest milk extract of $6530.4 \mathrm{~g} \mathrm{~kg}^{1}$.

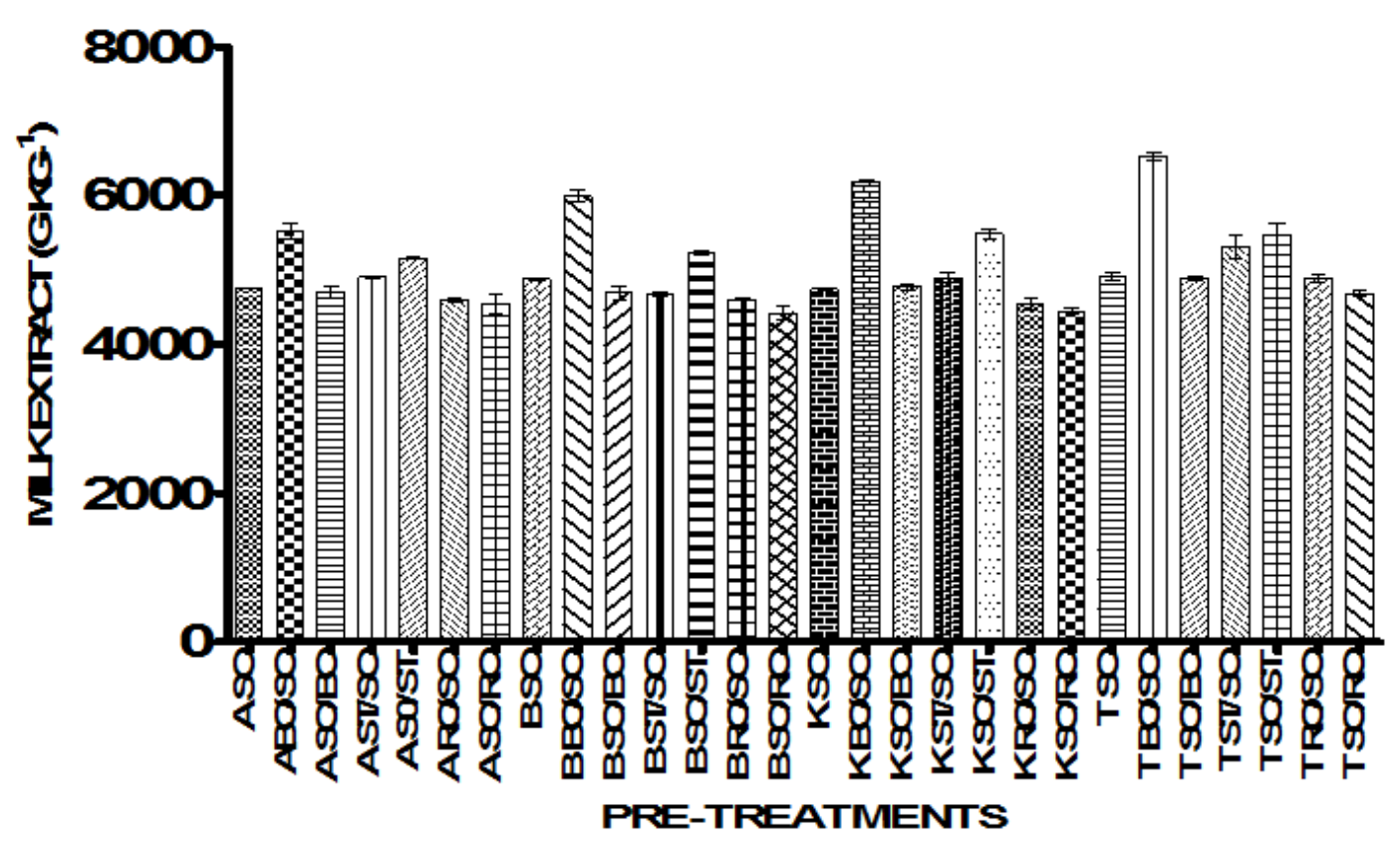

Figure 3. Effect of pre-treatment on milk yield 
Key; A, Ampenyi: B, Tampiong; K, kwahu; T, Twifo Praso; SO, soaking; BO/SO, boiling and soaking; SO/BO, soaking and boiling; ST/SO, steaming and soaking; SO/ST, soaking and steaming; RO/SO, roasting and soaking; $\mathrm{SO} / \mathrm{RO}$, soaking and roasting.

While black tubers from Ampenyi gave the lowest milk extract of $5477.9 \mathrm{~g} \mathrm{~kg}^{1}$

Soaking before roasting of tubers however gave the lowest milk yield with black tubers from Tampiong recording the lowest of $4395.5 \mathrm{~g} \mathrm{~kg}^{-}{ }^{1}$. Higher milk yield from boiling and soaking could be attributed to better opening of cellular pores and weakening of cell walls after milling of tubers (Djomdi Ejoh and Ndjouenkeu, 2006; Ndjouenkeu and Djomdi Ejoh, 2007).

Though boiling before soaking gave the highest milk yield, it recorded the lowest milk solids for both varieties and all sites with the lowest of $101.0 \mathrm{~g} \mathrm{~kg}^{1}{ }^{1}$ recorded for black tubers from Tampiong as shown in Figure 4.

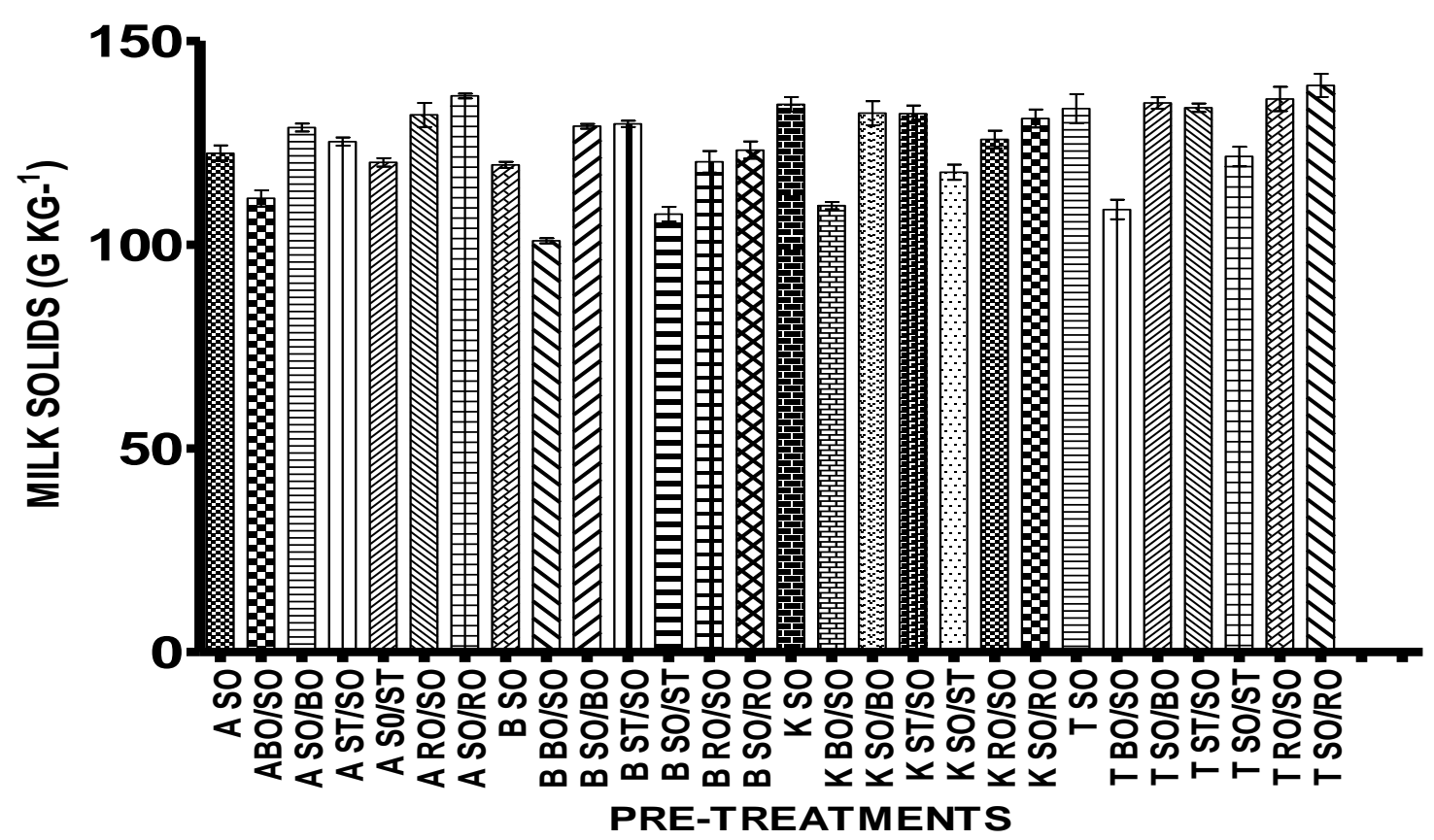

Figure 4. Effect of pre-treatment on milk solids

Key; A, Ampenyi: B, Tampiong; K, kwahu; T, Twifo Praso; SO, soaking; BO/SO, boiling and soaking; SO/BO, soaking and boiling; ST/SO, steaming and soaking; SO/ST, soaking and steaming; $\mathrm{RO} / \mathrm{SO}$, roasting and soaking; $\mathrm{SO} / \mathrm{RO}$, soaking and roasting.

This could be due to the gelling of starch from boiling resulting in the trapping of solids in the filter cloth. Fig. 5 shows the expected milk solids for all pre-treatments. A range of $541.4 \mathrm{~g} \mathrm{kg-}{ }^{1}$ to $619.4 \mathrm{~g} \mathrm{~kg}^{1}{ }^{1}$ was recorded for black tubers from Ampenyi and Tampiong with the lowest recorded for soaked and roasted black tubers from Tampiong and the highest recorded for soaked and boiled black tubers from Ampenyi . 


\section{MInstitute Macrothink $^{m}$}

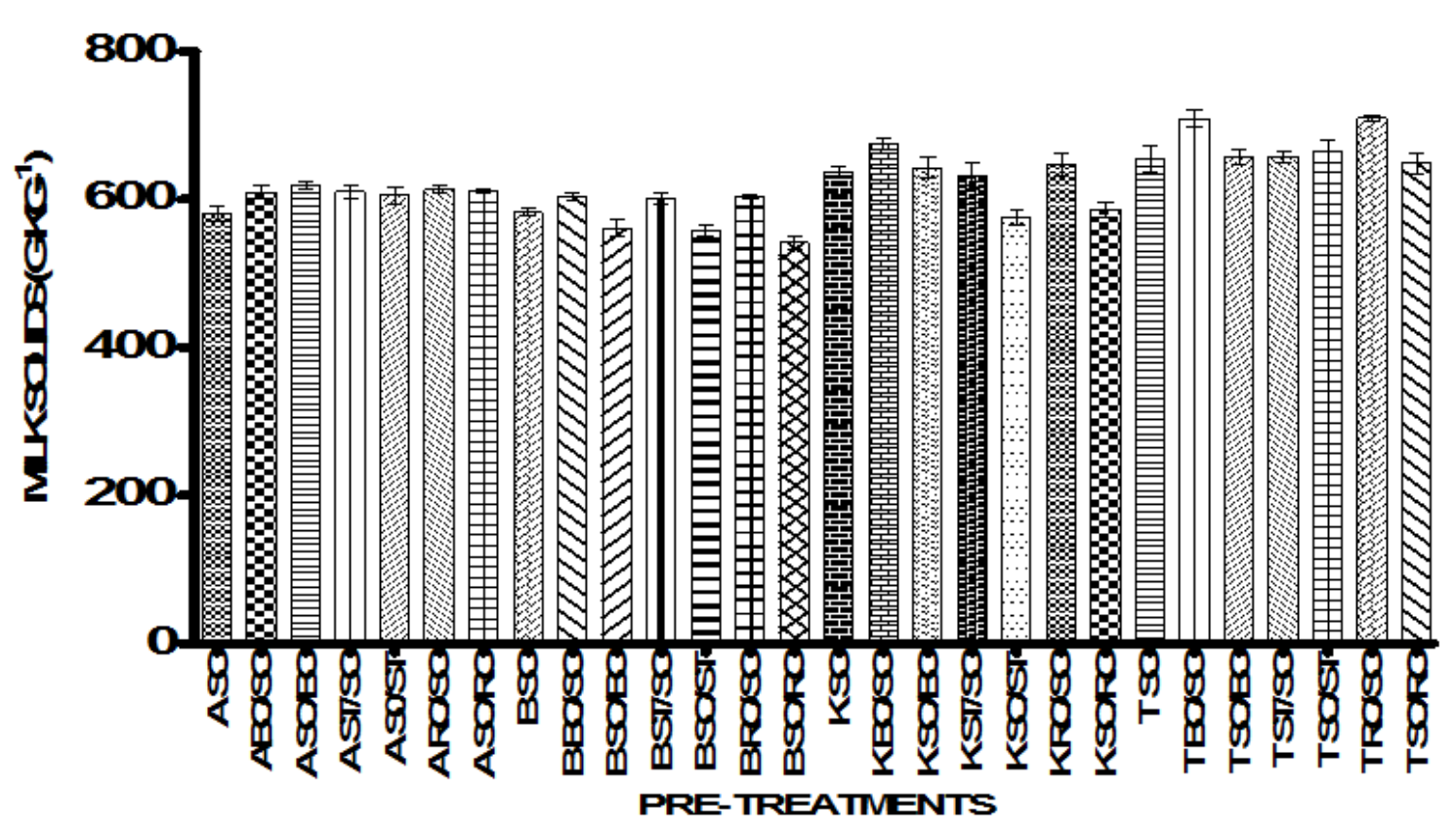

Figure 5. Effect of pre-treatment on expected milk solids

Key; A, Ampenyi: B, Tampiong; K, kwahu; T, Twifo Praso; SO, soaking; BO/SO, boiling and soaking; SO/BO, soaking and boiling; ST/SO, steaming and soaking; SO/ST, soaking and steaming; $\mathrm{RO} / \mathrm{SO}$, roasting and soaking; $\mathrm{SO} / \mathrm{RO}$, soaking and roasting.

A range of $571.4 \mathrm{~g} \mathrm{~kg}^{1}{ }^{1}$ to $710.2 \mathrm{~g} \mathrm{~kg}^{-1}$ was however recorded for brown tubers from Kwahu and Twifo Praso with the lowest recorded for steamed and soaked brown tubers from kwahu and the highest recorded for roasted and soaked brown tubers from Twifo Praso . This was however not significantly different from the yield obtained from soaked and boiled brown tubers fromTwifo Praso.

\subsection{Sensory Quality of Milk from Pretreated Tubers}

The milks of Ampenyi black and Twifo Praso brown tubers were selected for sensory quality evaluation because of the potential of the tubers from these sites to yield higher milk solids (based on the data from table 1). The results in Table 2 show that the different pre-treatments of Ampenyi black tubers did not result in any significant differences in the flavor, after taste and overall acceptability.

Table 2. Sensory quality of milk from different pretreated tubers

\begin{tabular}{|c|c|c|c|c|c|c|}
\hline \multirow{2}{*}{ PRE-TREATMENT } & \multicolumn{3}{|l|}{ BLACK TUBERS (AMPENYI) } & \multicolumn{2}{l|}{ BROWN TUBERS (TWIFO PRASO ) } \\
\cline { 2 - 7 } & Flavor & After taste & Overall acceptability & Flavor & After taste & Overall acceptability \\
\hline SO & $7.1^{\mathrm{a}}$ & $6.8^{\mathrm{a}}$ & $7.0^{\mathrm{a}}$ & $6.0^{\mathrm{a}}$ & $5.8^{\mathrm{a}}$ & $5.8^{\mathrm{a}}$ \\
\hline $\mathrm{BO} / \mathrm{SO}$ & $6.4^{\mathrm{a}}$ & $6.4^{\mathrm{a}}$ & $6.1^{\mathrm{a}}$ & $5.9^{\mathrm{a}}$ & $5.8^{\mathrm{a}}$ & $6.0^{\mathrm{a}}$ \\
\hline $\mathrm{SO} / \mathrm{BO}$ & $6.4^{\mathrm{a}}$ & $6.4^{\mathrm{a}}$ & $6.4^{\mathrm{a}}$ & $5.5^{\mathrm{a}}$ & $5.5^{\mathrm{a}}$ & $5.7^{\mathrm{a}}$ \\
\hline $\mathrm{ST} / \mathrm{SO}$ & $5.8^{\mathrm{a}}$ & $6.0^{\mathrm{a}}$ & $5.8^{\mathrm{a}}$ & $5.9^{\mathrm{a}}$ & $5.6^{\mathrm{a}}$ & $5.9^{\mathrm{a}}$ \\
\hline $\mathrm{SO} / \mathrm{ST}$ & $6.5^{\mathrm{a}}$ & $6.3^{\mathrm{a}}$ & $6.7^{\mathrm{a}}$ & $5.6^{\mathrm{a}}$ & $5.6^{\mathrm{a}}$ & $5.7^{\mathrm{a}}$ \\
\hline $\mathrm{RO} / \mathrm{SO}$ & $6.9^{\mathrm{a}}$ & $6.4^{\mathrm{a}}$ & $6.4^{\mathrm{a}}$ & $7.1^{\mathrm{b}}$ & $6.4^{\mathrm{a}}$ & $6.5^{\mathrm{a}}$ \\
\hline $\mathrm{SO} / \mathrm{RO}$ & $7.0^{\mathrm{a}}$ & $6.5^{\mathrm{a}}$ & $7.0^{\mathrm{a}}$ & $6.2^{\mathrm{a}}$ & $6.3^{\mathrm{a}}$ & $6.4^{\mathrm{a}}$ \\
\hline
\end{tabular}


SO; soaking; BO/SO, boiling and soaking; SO/BO, soaking and boiling; ST/SO, steaming and soaking; SO/ST, soaking and steaming; RO/SO, roasting and soaking; SO/RO, soaking and roasting

Means in the same column with the same superscript are not significantly different $(p<0.05)$

All the pretreatments were acceptable at varying degrees. The flavor of milk produced from roasted and soaked brown tubers from Twifo Praso was however most preferred to the milk from other pretreatments. The observation that roasting before soaking give a more acceptable milk is similar to studies reported for sesame (Quasem, Mazahreh and Abu-Alruz, 2009). It was to be expected since roasting is known to improve upon the flavor of food stuffs (Fox and Cameron, 1989). There was however no significant differences in the after taste and overall acceptability of the milks.

\section{Conclusion}

Tiger nut tubers grown at different sites do not have the same potential for milk and solids. Pre-treating tubers by soaking and cooking improved the expected milk solids of milk. The boiled and soaked as well as roasted and soaked tubers gave the most milk solids. Though the different cooking methods in combination with soaking had no effect on the sensory quality of milk from the black tubers, it did have an effect on milk from the brown tubers. Milk from tubers that were roasted before soaking had the most acceptable flavor.

\section{References}

Adekanmi, O. K., Oluwatooyin, O. F., \& Yemisi, A. A. (2009). Influence of processing techniques on the nutrients and anti-nutrients of tigernut (Cyperus esculentus L.). World Journal of Dairy \& Food Science, 4, 88-93.

Aidoo, H., Sakyi-Dawson, E., Tano-Debrah, K., \& Saalia, F. K. (2010). Development and characterization of dehydrated peanut-cowpea milk powder for use as a dairy milk substitute in chocolate manufacture. Food Research International, 43, 79-85. http://dx.doi.org/10.1016/j.foodres.2009.08.018

Belewu, M. A., \& Belewu, K. Y. (2007). Comparative physico-chemical evaluation of tiger-nut, soybean and coconut milk sources. International Journal of Agricultural Biology, 9, 785-787

Cochran, W. G. \& Cox, G. M. (1957). Experimental designs. New York, John Wiley \&Sons, 469.

Cortés, C., Esteve, M. J., Frgola, A. \& Torregrosa, F. (2004). Physical and chemical properties of different commercially available types of "horchata de chufa". Italian Journal of Food Science, 1, 113-121.

Cortés, C., Esteve, M.J., Frgola, A. \& Torregrosa, F. (2005). Quality characteristics of hortacha (a Spanish vegetable beverage) treated with pulsed electric fields during shelf- life. Food Chemistry, 91, 319-325. http://dx.doi.org/10.1016/j.foodchem.2004.06.014

Diarra, K., Nong, Z. G., \& Jie, C. (2005) Peanut milk and peanut milk based products 
production: A review. Critical Review Food Science \& Nutrition, 45, 405-423. http://dx.doi.org/10.1080/10408390590967685

Djomdi Ejoh, R., \& Ndjouenkeu, R. (2006). Soaking behavior and milk extraction performance of tiger nut (Cyperus esculentus) tubers. Journal of Food Engineering, 78, 546-550. http://dx.doi.org/10.1016/j.jfoodeng.2005.10.022

Dokosi, O. B. (1998). Herbs of Ghana. Accra, Ghana University Press, pp 548, 549

Edwards, E. V. (1998). Milk Recipes from Nut \& Seeds. Brushton, New York, Teach Services, Inc.

El-Agamy, E. I. (2007). The challenge of cow milk protein allergy. Small Ruminant Research, 68, 64-72. http://dx.doi.org/10.1016/j.smallrumres.2006.09.016

Enneking, D., \& Wink, M. (2000). Toward the elimination of anti nutritional factors in grain legumes. In Knight, R. (ed.). Linking Research and Marketing Opportunities for Pulses in the 21st Century. Proceedings of the Third International Food Legume Research Conference, Adelaide 1997. Current Plant Science and Biotechnology in Agriculture. 34. (pp.375-384); London, Kluwer Academic Publishers,

Fox, B. A., \& Cameron, A. G. (1989). Food Science, Nutrition and Health. Kent, Edward Arnold, 285-304.

Isanga, J., \& Zhang, G. (2009). Production and evaluation of some physicochemical parameters of peanut milk yoghurt, LWT-Food Science and Technology, 42, 1132-1138.

Kashid, U. B., Sontakke, A. T., \& Shined, D. B. (2007). Manufacture of golden milk shake from cow milk blended with safflower milk. Journal of Dairying Foods \& Home Science, 26, 159-163.

Liener, I. E., (1994). Implications of anti-nutritional components in soybean foods. CRC Critical Reviews in Food Science and Nutrition, 34, 31-67. http://dx.doi.org/10.1080/10408399409527649

Liu, K. (1997). Soybean Chemistry, Technology \& Utilization. New York, NY Chapman and Hall, 1000Pp

Mosquera, L. A., Sims, C. A., Bates, R. P., \& Okeefe, S. F. (1996). Flavor and Stability of Horchata De Chufas. Journal of Food Science, 61, 856-861. http://dx.doi.org/10.1111/j.1365-2621.1996.tb12219.x

Ndjouenkeu, R. \& Djomdi Ejoh, R. (2007). Characteristics of tiger nut (Cyperus esculentus L.) tubers and their performance in the production of a milky drink. Journal of Food Processing \& Preservation, 3, 145-163.

Quasem, J. M., Mazahreh, A. S., \& Abu-Alruz, K. (2009). Development of Vegetable Based Milk from Decorticated Sesame (Sesamum Indicum). American Journal of Applied Science, 6, 888-896. http://dx.doi.org/10.3844/ajassp.2009.888.896 


\section{Macrothink}

Journal of Agricultural Studies

ISSN 2166-0379 2014, Vol. 2, No. 2

Rubert, J., Soler, C. \& Manes, J. (2012). Occurrence of fourteen mycotoxins in tiger-nuts. Food Control, 25, 374-379. http://dx.doi.org/10.1016/j.foodcont.2011.11.004

Russell, K. \& Delahunty, C. (2004). The effect of viscosity and volume on pleasantness and satiating power of rice milk. Food Quality and Preference, 15, 743-750. http://dx.doi.org/10.1016/j.foodqual.2003.07.005

Tigernuts Traders, S. L. (2010). Profile on Tiger nuts. http://www.tigernuts.milk.profile.pdf (Accessed November 2010)

Tunde-Akintunde T. Y., \& Souley, A. (2009). Effect of processing methods on the quality of soymilk. Pakistan Journal of Nutrition 8, 1156-1158. http://dx.doi.org/10.3923/pjn.2009.1156.1158

Wang, H. (1980). The importance of traditional fermented foods. Biological Science, 30, 402-404.

Ye, C., \& Jiang, C. (2011). Optimization of extraction process of crude polysaccharides from Plantago asiatica L.by response surface methodology. Carbohydrate Polymers, 84, 495-502. http://dx.doi.org/10.1016/j.carbpol.2010.12.014

\section{Copyright Disclaimer}

Copyright for this article is retained by the author(s), with first publication rights granted to the journal.

This is an open-access article distributed under the terms and conditions of the Creative Commons Attribution license (http://creativecommons.org/licenses/by/3.0/). 